\title{
PERCEPTIONS OF PUBLIC SERVICES USEFULNESS PROVIDED BY PUBLIC LIBRARIES - CASE STUDY
}

\author{
[Vnímání užitečnosti veřejných služeb poskytovaných knihovnami - případová \\ studie]
}

\author{
Pavla Kot’átková Stránská ${ }^{1}$, Kateřina Nekolová $^{2}$, Jan Stejskal $^{3}$ \\ ${ }^{I}$ Univerzita Pardubice, Fakulta ekonomicko-správní, Studentská 84, 53210 Pardubice \\ Email:pavla.kotatkovastranska@upce.cz \\ ${ }^{2}$ GASCO spol. s r.o., 53003 Pardubice \\ Email: nekolovakaterina@gmail.com \\ ${ }^{3}$ Univerzita Pardubice, Fakulta ekonomicko-správní, Studentská 84, 53210 Pardubice \\ Email:jan.stejskal@upce.cz.
}

\begin{abstract}
The scientific studies are focused on the evaluation and the general perception of the public services value by their consumers. The benefit what flows from consumption of the services is in the middle of the interest. This paper focuses on the verification that the library consumers take in and evaluate the importance of the services. They can do it by answering the question about "willingness to pay" for the library services (contingent valuation method). The paper analyses the dependence between willingness to pay and disposable income of the consumers. Next we want to present the application of the approaches based on willingness to pay by the tax assignation. It contains also the application of methods and summarizes the results what have been never presented in Czech Republic in library research field.
\end{abstract}

Keywords: public services, Municipal Library in Prague, WTP, benefit.

JEL classification: H41, H49

Doručeno redakci: 23.2.2014; Recenzováno: 15.5.2014; 15.5.2014; Schváleno k publikování: 23.9.2014

\section{Úvod}

Spotřebou veřejných služeb se jednotlivci snaží uspokojit pocit'ovanou potřebu, která může mít charakter informační, vzdělávací, kulturní, atd. Potřebu získávání informací či vzdělání se snaží jednotlivci uspokojit mj. i spotřebováváním služeb poskytovaných veřejnými knihovnami, resp. spotřebou vybraných knihovnických služeb. Nabídka těchto služeb je často odvislá od objemu finančních prostředků plynoucích převážně z veřejných rozpočtů. Vzhledem knedostatku prostředků je nezbytné zkoumat efektivnost poskytovaných knihovnických služeb a zdůvodnit tak oprávněnost finančních nároků na zajištění těchto služeb i v budoucnosti.

Za efektivně poskytované veřejné služby jsou považovány ty, z jejichž spotřeby a užití vyplývají vyšší užitky (benefity) než náklady na jejich vznik. Má-li být tato analýza prováděna a sloužit jako manažerský nástroj, musí existovat způsob, jak určit hodnotu veřejných služeb jejich spotřebiteli.

Mnohé vědecké studie ${ }^{1}$ se zaměřují na ohodnocení vnímané hodnoty knihovnických služeb. Cílem vědeckých studií je prokázat, že užitek je možné identifikovat a za pomoci vhodných metod ohodnotit. Podobný výzkum v českém prostředí nebyl doposud realizován.

\footnotetext{
${ }^{1}$ Např́iklad: Ohio, S. Value for Money: Southwestern Ohio's Return from Investment in Public Library. Driscoll \& Fleeter. Columbus, $\mathrm{OH}, 2006$, s. 50.; British Library. Measuring our value, British Library Annual Report
} 
Cílem tohoto příspěvku je zjistit, jak uživatelé Městské knihovny v Praze (dále jen „MKP“) vnímají užitečnost jimi spotřebovávaných knihovnických služeb. Užitečnost bude měřena metodou ochoty platit daný užitek služby př́mo ze svého důchodu spotřebitele na základě porovnání preferencí spotřebitele. Ochotou platit vyjadřují svou schopnost ocenit užitek plynoucí ze spotřeby knihovnických služeb.

V souladu s uvedeným cílem byly stanoveny tři výzkumné otázky (dále jen „VO“), které budou řešeny v tomto príspěvku. Jsou jimi:

VO1. Existuje závislost mezi ochotou platit a disponibilním důchodem uživatelů knihovny? Pokud závislost existuje, lze říci, že mezi ochotou platit a disponibilním důchodem je pozitivní vztah (př́má závislost)?

VO2. Existuje diferenciace ochoty platit mezi jednotlivými př́ijmovými skupinami domácností?

VO3. Jsou uživatelé ochotni platit alespoň skutečné provozní náklady knihovny?

\section{Teoretický rámec}

\subsection{Definice knihovnických služeb}

Definice knihovnických služeb, zabezpečovaných veřejnými knihovnami, lze nalézt v zákoně o knihovnách a dokumentech, které vymezí základní portfolio poskytovaných služeb 2 .

Knihovnické služby lze obecně definovat jako služby knihoven sloužící k uspokojení potřeb občanů v oblasti poznání a informací a kultury. Jedná se o služby, které spadají do skupiny veřejných služeb a jsou poskytovány všem občanům bez rozdílu jejich pohlaví, rasy, náboženství, občanství, tělesného a duševního zdraví, politického a kulturního vyznání atd. (Maine State Library; Ohio, 2006; Směrnice IFLA/UNESCO)

\subsection{Př́́stupy k ocenění knihovnických služeb}

V současné době je $\mathrm{k}$ dispozici celá řada zahraničních vědeckých studií zaměřených na ocenění služeb veřejných knihoven. Mezi nejznámější studie tohoto typu patří studie provedené na Floridě, v Ohiu, Jižní Karolíně a Velké Británii, přičemž studie z Floridy a Velké Británie jsou odborníky na danou problematiku považovány za vůdčí studie v oceňování knihovnických služeb. (AABO, 2009; BARRON, 2005; British Library, 2004; GRIFFITHS, 2004a; GRIFFITHS, 2004b; CHUNG，2008; KIM，2011; Ohio，2006; STEJSKAL, 2012)

Z výše uvedených studií vyplynul soubor několika metod oceňování, které jsou využitelné ke stanovení vnímané hodnoty veřejné služby. Mezi nejznámější používané metody patří: (GRIFFITHS, 2004a)

- analýza nákladů a př́nosů (CBA);

- návratnost investice (ROI);

2003/2004, 2004, s. 6. Dostupné na www: http://www.bl.uk/pdf/measuring.pdf; Lynch, T. A study of taxpayer return on investment (ROI) in Florida public libraries: Part III - REMI details. Tallahassee, FL: State Library and Archives of Florida , 2004, s. 21; Barron, D. D., et al. The Economic Impact of Public Libraries on South Carolina: A Study Prepared by the School of Library and Information Science, University of South Carolina. Columbia, SC: School of Library and Information Science, University of South Carolina, Leden 2005, s. 4. Dostupné na www: http://www.libsci.sc.edu/SCEIS/exsummary.pdf

2 Mezi základní a důležité dokumenty definující knihovnické služby patř́i: Knihovní zákon (z. č. 257/2001 Sb.); Směrnice IFLA/UNESCO pro rozvoj;Manifest IFLA/UNESCO o veřejných knihovnách; Glasgowská deklarace o knihovnách, informačních službách a intelektuální svobodě; Doporučení č. r (99) 14 Rady Evropy; Metodický pokyn Ministerstva kultury k vymezení standardu veřejných knihovnických a informačních služeb poskytovaných knihovnami zřizovanými a/nebo provozovanými obcemi a kraji na území České republiky. 
- metoda kontingentního oceňování (CV);

- přebytek spotřebitele;

- kombinace uvedených metod.

Všechny uvedené metody však musí vyřešit stejný problém - tedy obtížnou měřitelnost nehmotných výsledků služeb. Pro řešení existují dva hlavní př́stupy, a to: (AABO, 2005)

- některé (nepřímé) metody se spoléhají na pozorování chování na trzích, z něhož je hodnota odvozena pomocí ekonomických modelů. Vysvětluje se tak vztah mezi příslušným chováním a hodnotou netržních statků. Tento př́stup bývá označován jako přístup odhalených preferencí (RP).

- některé (přímé) metody nacházejí hodnotu přímo, přes dotazování vzorku spotřebitelů. Tento př́stup je označován jako přístup sdělených preferencí (SP). Přístupy SP zahrnují hypotetické metody pro př́mé ocenění.

Výhodou př́stupu SP je v zachycení celkové hodnoty veřejného statku jak s jeho užitnou, tak i neužitnou hodnotou, zatímco přístupy RP zachycují pouze užitnou hodnotu. SP př́stupy využívají metodu kontingentního oceňování, která je založena na reprezentativním dotazníkovém šetření o oceňování veřejných služeb. Nejčastěji se pro tento druh empirického zjišt'ování využívá dotazování na ochotu platit za spotřebu veřejné služby (WTP z angl. willingness to pay) nebo ochotu přijmout kompenzaci za nespotřebovávání (WTA z angl. willingness to accept compensation). Nejčastěji se v praxi využívá př́stup WTP (HARLESS, 1999). A to proto, že studie zaměřené na stanovení preferencí ukázaly významné rozdíly ve výsledcích při použití WTA a WTP. Nejvýznamnějším rozdílem je fakt, že při použití metody WTA jsou uváděny zpravidla vyšší hodnoty, než při využití metody WTP. Toto zjištění vyplývá z faktu, že pokud respondenti rozhodují o nákladech, které sami ponesou (v př́padě metody WTP), budou odhady těchto nákladů vždy podhodnoceny, než pokud budou respondenti zvažovat kompenzaci, která jim bude poskytnuta např́klad z veřejných zdrojů ( $v$ př́padě metody WTA). (STEJSKAL, 2013) Toto představuje určité riziko vypovídací schopnosti, které je nezbytné respektovat při interpretaci zjištěných výsledků. Ochota platit (WTP) je metodou zkoumání ochoty subjektu platit za určitou službu. Vyjadřuje peněžní částku, jejíž obětování je pro subjekt naprosto shodné jako zachování status quo (v prŕípadě kladného efektu), nebo také peněžní částku, při jejímž přijetí je subjekt indiferentní mezi ní a spotřebou daného statku (v př́ípadě negativního efektu). (Směrnice IFLA/UNESCO)

\section{Metodika výzkumu}

Ve výzkumu byla použita pro ocenění knihovnických služeb metoda kontingentního oceňování s aplikací př́istupu WTP a WTA. Primární data vstupující do metod WTP a WTA byla získána pomocí empirického dotazníkového šetření formou elektronické verze dotazníku (typ CAWI - Computer Assisted Web Interviewing). Dotazníkové šetření proběhlo v roce 2012 u vybrané veřejné knihovny, a to Městské knihovny v Praze (dále jen MKP).

Seznam otázek (metoda kontingentního oceňování, přístup WTP), které byly položeny s cílem zjistit, jak vnímaní hodnotu knihovnických služeb, je následující:

- Jakou částku byste byl/a ochotný/á ročně platit na fungování knihovny z vašeho disponibilního důchodu (tzv. z vlastní kapsy)?

- Představte si, že byste mohl/a rozhodovat o tom, jak se naloží s 10000 Kč z vámi placených daní. Tuto částku byste mohl/a rozdělit libovolně mezi neziskové organizace jako jsou školy, divadla, galerie, ZOO, charita apod. Pokud by byla tato možnost, připsal/a byste něco z této částky knihovně? 
- Knihovna je nyní financována z rozpočtu hlavního města Prahy. Když rozpočítáme současné náklady mezi všechny čtenáře, vychází to na 1 400,- Kč na 1 čtenáře. Přredstavte si, že by se zcela změnil systém financování knihovny a knihovna by byla financována pouze $\mathrm{z}$ ročních členských prríspěvků od čtenářu. Byl/a byste ochotný/á platit tuto částku, tedy 1 400,- Kč za rok?

V souvislosti s aplikací př́stupu WTA, byla položena tato otázka:

- Představte si, že knihovna přestala přijímat nové čtenáře, ale stávající čtenáři mohou převést svoji legitimaci na začátku každého roku na někoho jiného, kdo bude místo nich využívat služby knihovny. Jakou nejmenší částku byste přijal/a za to, že byste převedl/a na 1 rok členství v knihovně na někoho jiného? Nápověda: Legitimaci do knihovny (členství v MKP) byste mohl/a prevést pouze na 1 rok, po celý rok byste pak nemohl/a využívat služeb knihovny, ale v dalším roce byste opět získal/a novou.

Výzkum byl zaměřen na kvantifikaci užitku plynoucího z existence veřejné knihovny, resp. z existence nabídky veřejných služeb konečným spotřebitelům. Základní panel respondentů tvořili pouze návštěvníci MKP. Celkový počet respondentů, kteří se zúčastnili dotazníkového šetření v období července a srpna 2012, byl 222.

Mezi členy panelu MKP byli náhodně vybráni uživatelé MKP, kteří splnili tato kritéria: (HÁJEK, 2012)

- věk 15+ (1994 a starší);

- alespoň 1 výpůjčka v roce 2012;

- uvedena e-mailová adresa;

- odpověděli v prvním kole dotazování, tedy souhlasili se zařazením do panelu.

Základní soubor tvořil celkem 2227 respondentů (z toho 1678 žen a 549 mužů). Základní přehled je uveden $\mathrm{v}$ Tab. 1, který ukazuje strukturu výběrového vzorku respondentů pro potřeby dotazníkového šetření z hlediska věkové struktury. Charakter výzkumu byl zvolen jako reprezentativní, nebot' výsledky reprezentativního výzkumu lze zevšeobecnit.

Tabulka 1: Základní informace o základním souboru v porovnání se skutečnými četnostmi z hlediska věkových kategorií

\begin{tabular}{|c|c|c|c|c|c|c|}
\hline \multirow{2}{*}{$\begin{array}{c}\text { Věková } \\
\text { kategorie }\end{array}$} & \multicolumn{3}{|c|}{ Výběrový vzorek } & \multicolumn{2}{c|}{ Počet čtenářů MKP 15+ v r. 2012 } & Odchylka \\
\cline { 2 - 7 } & $\mathrm{N}$ & Podíl kategorie & Počet platných & $\mathrm{N}$ & $\%$ & $\%$ \\
\hline $\mathbf{1 5 - 1 9}$ & 162 & $7 \%$ & $8 \%$ & 18393 & $12 \%$ & $-4 \%$ \\
\hline $\mathbf{2 0 - 2 4}$ & 298 & $13 \%$ & $14 \%$ & 28412 & $18 \%$ & $-4 \%$ \\
\hline $\mathbf{2 5 - 2 9}$ & 252 & $11 \%$ & $12 \%$ & 20656 & $13 \%$ & $-1 \%$ \\
\hline $\mathbf{3 0 - 3 4}$ & 210 & $9 \%$ & $10 \%$ & 15922 & $10 \%$ & $0 \%$ \\
\hline $\mathbf{3 5 - 3 9}$ & 285 & $13 \%$ & $13 \%$ & 15662 & $10 \%$ & $3 \%$ \\
\hline $\mathbf{4 0 - 4 9}$ & 343 & $15 \%$ & $16 \%$ & 20087 & $13 \%$ & $3 \%$ \\
\hline $\mathbf{5 0}$ a více & 602 & $27 \%$ & $28 \%$ & 40094 & $25 \%$ & $3 \%$ \\
\hline Bez odpovědi & 75 & $3 \%$ & & & & $100 \%$ \\
\hline Celkem & 2227 & $100 \%$ & $100 \%$ & 159226 & & \\
\hline
\end{tabular}

Zdroj: vlastní zpracování dle dotazníkového šetření 
Pro verifikaci, v úvodu stanovených výzkumných otázek, je využita grafická interpretace s využitím popisných statistik s uvedením korelačního vztahu mezi sledovanými veličinami.

Korelační vztah bude analyzován pomocí hodnoty koeficientu korelace. Výpočet hodnoty korelačního koeficientu bude proveden pomocí statistického softwaru STATISTICA verze 10.1. Na základě vypočtené hodnoty koeficientu korelace lze určit, jak těsný je mezi nimi vzájemný (korelační) vztah. Koeficient korelace může nabývat hodnoty v rozmezí -1 a 1 včetně. $\mathrm{V}$ príípadě, že se blíží hodnota koeficientu korelace $\mathrm{k}$ hodnotě -1 , resp. 1, lze hovořit o velmi silném vzájemném korelačním vztahu mezi sledovanými veličinami. Dále lze odlišit pozitivní korelační vztah (resp. přímý vztah), který nastává v případě, že hodnota koeficientu korelace nabývá kladných hodnot. Anebo v opačném případě se jedná o negativní korelační vztah (resp. nepř́mý vztah). Dále bude použita analýza rozptylu (resp. „Anova“) pro verifikaci existence významného rozdílu mezi průměrnou hodnotou vybraných proměnných v rámci jednotlivých př́jmových skupin domácností. Hladina významnosti pro statistickou analýzu je stanovena na úrovni 0,05. (HINDLS, 2007; TROSBY, 2003)

\section{Výsledky výzkumu}

Ústředním problémem celého výzkumu bylo zjistit, zda jsou spotřebitelé ochotni za spotřebovávanou veřejnou službu platit. Ve výzkumu byly využity přístupy WTP a WTA. Výsledky z dotazníkového šetření v rámci aplikace přístupu WTP, uvádí níže uvedená Tab. 2.

Tabulka 2: Základní popisné statistiky pro „ochotu platit““

\begin{tabular}{|l|c|c|c|c|c|c|}
\hline Proměnná & Průměr & Medián & $\begin{array}{c}\text { Směrodatná } \\
\text { odchylka }\end{array}$ & Min & Max & $\boldsymbol{N}$ \\
\hline $\begin{array}{l}\text { WTP ... Ochota platit } \\
\text { z vlastních prostředků [Kč] }\end{array}$ & 642 & 500 & 562 & 0 & 3000 & 1773 \\
\hline
\end{tabular}

Zdroj: vlastní zpracování dle dotazníkového šetření

Po analýze výsledků dotazníkového šetření lze souhrnně konstatovat, že uživatelé MPK:

- dokáží a jsou ochotni vyjádřit ochotu platit za knihovnické služby. Z celkového počtu respondentů se pozitivně vyjádřilo (že by byli ochotni platit) 79,61 \% respondentů;

- právě vyjádřená ochota platit za služby znamená, že si jejich uživatelé uvědomují jejich užitečnost (vzhledem k abstraktnosti dotazu uvádí různé vysoké částky);

- velikost př́spěvku odvisí od výše důchodu. Blíže viz Tab. 2.

Ze získaných výsledků vyplývá (viz souhrnná Tab. 2), že částka, kterou by respondenti byli ochotni přispět knihovně ze svého disponibilního důchodu, odpovídá hodnotě mediánu $500 \mathrm{Kč} /$ rok. Maximální částka, kterou byli respondenti ochotni ze svého disponibilního důchodu platit, odpovídá $3000 \mathrm{Kč} /$ rok.

Jak již bylo výše uvedeno, výsledky a závěry k ochotě platit za knihovnické služby mohou být zkresleny, resp. podhodnoceny. Proto autoři položili respondentům otázky směřující na ochotu přijmout kompenzaci za nespotřebovávání knihovnických služeb (resp. byla aplikována metoda WTA). Výsledky z dotazníkového šetření uvádí Tab. 3. 
Tabulka 3: Základní popisné statistiky pro „ochotu akceptovat kompenzaci“

\begin{tabular}{|l|c|c|c|c|c|c|}
\hline Proměnná & Průměr & Medián & $\begin{array}{c}\text { Směrodatná } \\
\text { odchylka }\end{array}$ & Min & Max & $\boldsymbol{N}$ \\
\hline $\begin{array}{l}\text { WTA ... Ochota akceptovat } \\
\text { kompenzaci [Kč] }\end{array}$ & 4024 & 200 & 27700 & 0 & 1000000 & 1845 \\
\hline
\end{tabular}

Zdroj: vlastní zpracování dle dotazníkového šetření

Výsledná částka ročního příspěvku knihovně vyjádřená hodnotou mediánu je přibližně 200 Kč (blíže viz Tab. 3). Tuto částku by zaplatilo 82,85 \% respondentů. Průměrná částka pak odpovídá hodnotě $4024 \mathrm{Kč}$, ale z důvodu existence extrémních hodnot v základním souboru (max. částka je 1 mil. Kč) je uvedená průměrná hodnota nevhodná a nelze ji považovat za vypovídající. Rozptýlenost jednotlivých částek v souboru doprovází vysoká hodnota směrodatné odchylky, která činí 27700.

\subsection{Analýza závislosti mezi ochotou platit a disponibilním důchodem (VO1)}

Respondenti dotazníkového šetření měli vyjádřit, jakou užitečnost vnímají u knihovnických služeb (pro potřeby této publikace omezeno pouze na bezplatné vypůjčení knih, časopisů a CD) tím, že stanovili částku, kterou by byli ochotni každý rok platit knihovně na financování vybraných knihovnických služeb.

Otázky, na které respondenti odpovídali, byly kladeny bez omezení finančního limitu (bez uvedení maximální částky). Výzkumný tým předpokládal (na základě dřivějších zkušeností) odlišnost odpovědí v př́ipadě, že respondent bude rozdělovat finanční prostředky z vlastního disponibilního důchodu v rámci WTP a nebo ochoty prijímat kompenzaci př́stupem WTA. Pro zjišsění intervalu, ve kterém se nalézá správná hodnota ocenění veřejné služby, byly využity oba př́stupy u stejné skupiny respondentů. Výsledné rozložení částek v rámci př́ijmových skupin domácností ${ }^{3}$ je zobrazeno na níže uvedených Obr. 1 a 2 . Z pilotních průzkumů vyplynulo, že ochota lidí platit se výrazně odlišuje s nabízeným platebním instrumentem, resp. vlivem placení na jejich disponibilní důchod. Tato odlišnost byla zkoumána prostřednictvím ochoty zaplatit ze svého disponibilního důchodu, resp. z odváděné daně (např́klad formou daňové asignace).

\footnotetext{
${ }^{3}$ Méně než 15000 Kč (1); 15 000-29 999 Kč (2); 30 000-44 999 Kč (3); 45 000-59 999 Kč (4); 60 000-74 999 Kč (5); více než 75000 Kč (6)
} 
Obrázek 1: Výsledky ze šetření ochoty platit z disponibilního důchodu dle př́ijmových skupin domácností

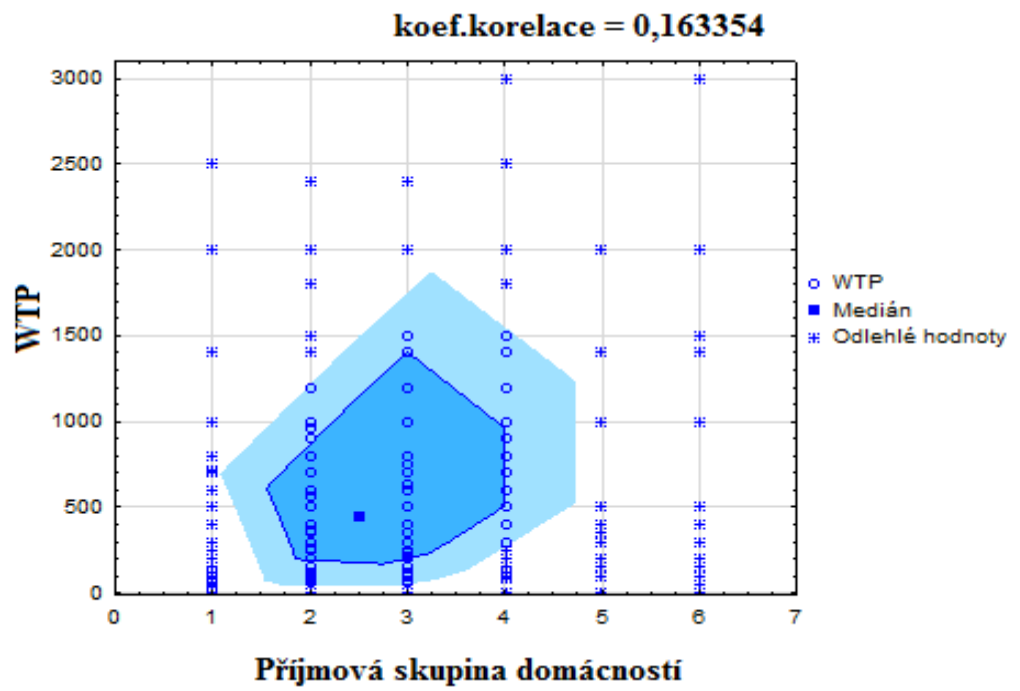

Poznámka: Př́imové skupiny domácností: Méně než 15000 Kč (1); $15000-29999$ Kč (2); $30000-44999$ Kč (3); 45 000-59 999 Kč (4); 60 000-74 999 Kč (5); více než 75000 Kč (6)

Zdroj: vlastní zpracování dle dotazníkového šetření

Z hlediska korelační analýzy (koeficient korelace činí 0,163354 - viz Obr. 1) byl na hladině významnosti $5 \%$ potvrzen statisticky významný vztah (p-hodnota dosáhla nižší hodnoty v komparaci s hladinou významnosti). Z výše uvedeného Obr. 1 je patrné, že dochází k vzájemnému pozitivnímu vztahu (resp. přímému vztahu) v př́ípadě přiřazení k prríslušné př́ijmové skupině domácností a ochotou platit knihovně určitou částku $\mathrm{z}$ disponibilního důchodu.

Obrázek 2: Výsledky ze šetření ochoty akceptovat kompenzaci z disponibilního důchodu po eliminaci odlehlých hodnot dle př́ijmových skupin domácností (eliminace hodnot nad $100000 \mathrm{~K} \check{c})$

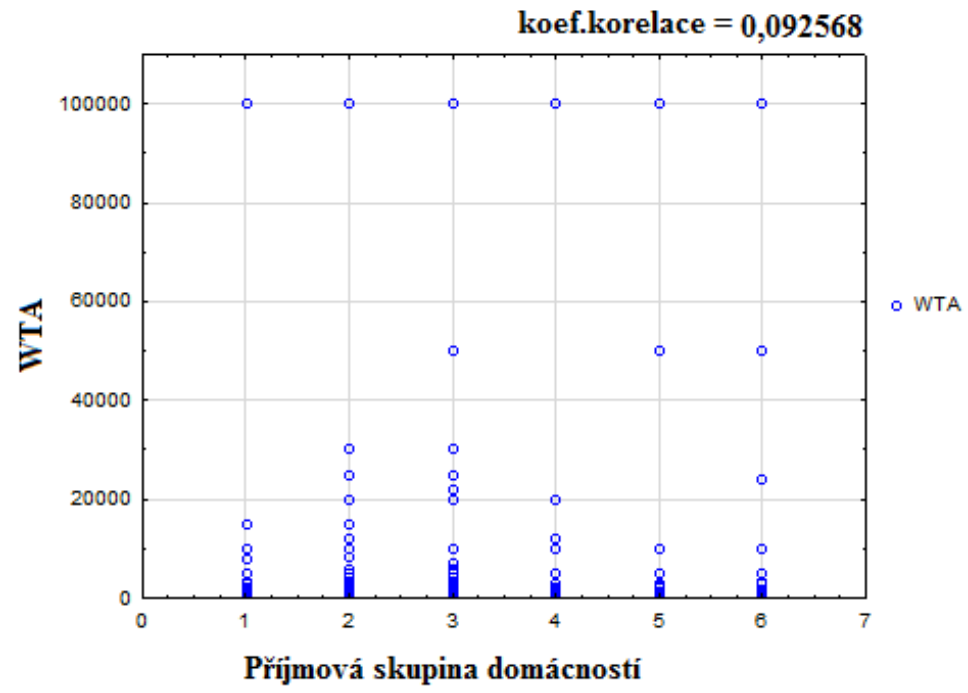

Zdroj: vlastní zpracování dle dotazníkového šetření

V př́ípadě posuzování vzájemného vztahu mezi přiřazením $\mathrm{k}$ příslušné př́ijmové skupině domácností a ochotou akceptovat kompenzaci ze svého disponibilního důchodu (viz Obr. 2) 
lze na základě provedené korelační analýzy konstatovat, že dochází opět k prokázání statisticky významného vlivu (přímý vztah).

$\mathrm{V}$ rámci závěrečného posouzení a ocenění knihovnických služeb s ohledem na oba př́istupy (WTA a WTP) je zachyceno na níže uvedeném Obr. 3.

Obrázek 3: Komparace ochoty platit a ochoty akceptovat kompenzaci

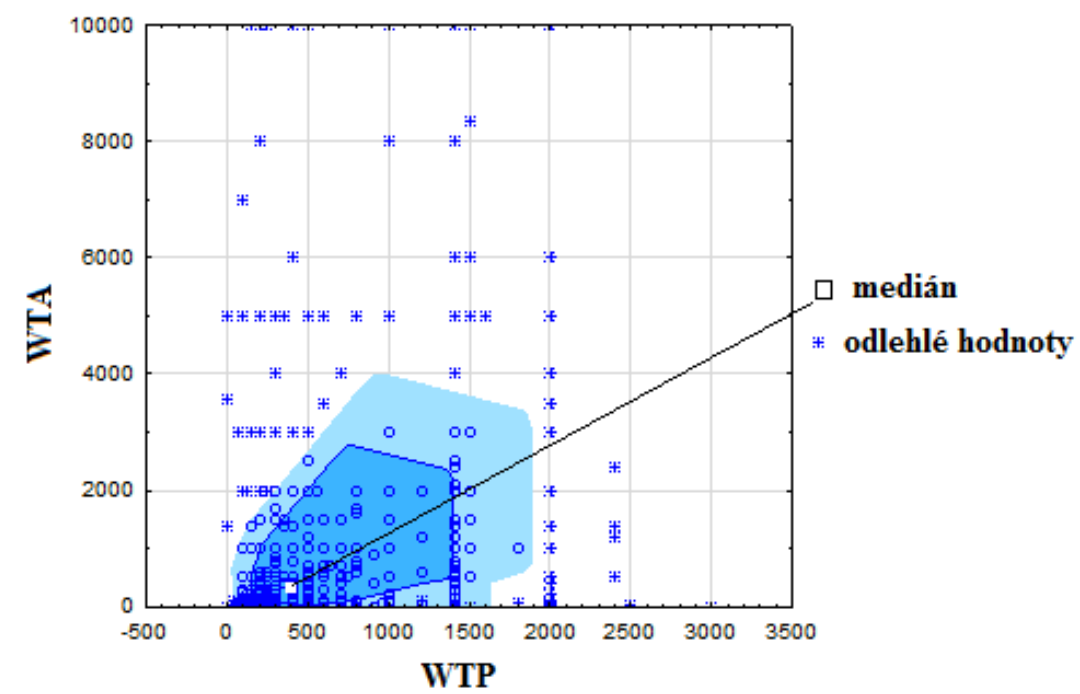

Zdroj: vlastní zpracování dle dotazníkového šetření

Na základě získaných výsledků a dílčích závěrů lze říci, že uživatelé vyjádřili svou ochotu platit roční př́spěvek knihovně v intervalu 200 Kč až 500 Kč. Průměrný roční příspěvek by tedy odpovídal hodnotě mediánu, tedy 350 Kč.

\subsection{Analýza diferenciace ochoty platit mezi jednotlivými př́ímovými skupinami domácností (VO2)}

Diferenciace ochoty platit mezi jednotlivými př́ijmovými skupinami domácností bude ověřena „Anovou, resp. analýzou rozptylu“. Anova testuje shodu středních hodnot, neboli zda existuje významný rozdíl mezi průměrnou hodnotou vybraných proměnných a jednotlivými (resp. šesti) prríjmovými skupinami domácností. Proměnnými pro tuto analýzu jsou ochota platit knihovně určitou částku ze svého disponibilního důchodu a ochota platit knihovně určitou částku z daňové asignace. (HINDLS, 2007; TROSBY, 2003)

Použití analýzy rozptylu je na základě splněných předpokladů, a to, že získaná data jsou nezávislá (pocházejí od různých respondentů), každý z výběrů respondentů pochází z normálního rozdělení pravděpodobností se stejnou směrodatnou odchylkou. Je stanovena nulová hypotéza $\left(\mathrm{H}_{0}\right)$ : všechny střední hodnoty náhodných výběrů jsou shodné. $\mathrm{K}$ verifikaci stanovené nulové hypotézy bude vycházeno z generované $p$-hodnoty, která bude následně porovnána se stanovenou hladinou významnosti 0,05 .

Výsledným řešením analýzy rozptylu je zamítnutí nulové hypotézy o shodě středních hodnot v obou prŕípadech (resp. proměnných). Blíže viz Obr. 4 a 5 . Grafická interpretace výsledků analýzy zobrazuje na ose „y“ 95 procentní intervaly spolehlivosti pro jednotlivé prŕjmové skupiny domácností s vyznačením př́slušného průměru metodou nejmenších čtverců. 
Obrázek 4: Výsledné řešení Anovy pro ochotu platit z daňové asignace

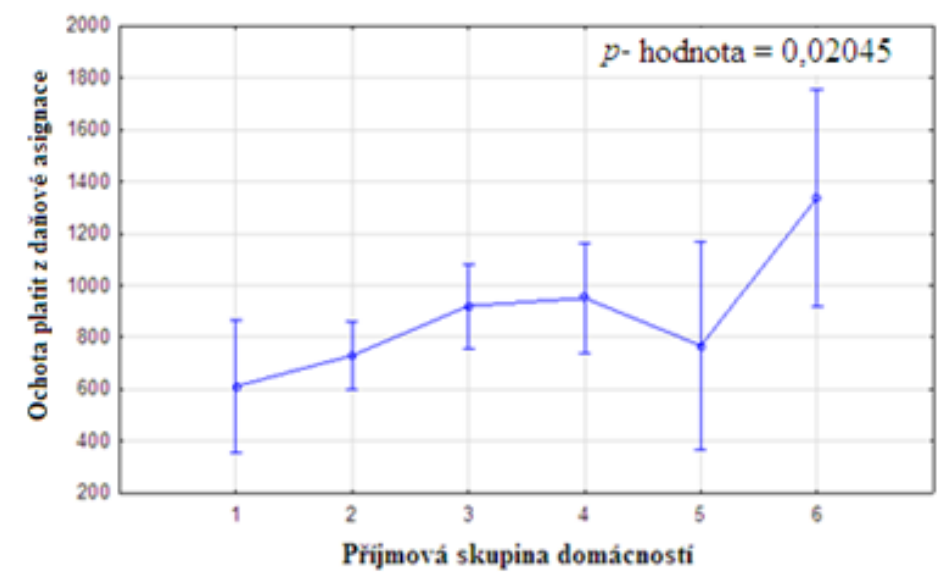

Zdroj: vlastní zpracování dle dotazníkového šetření

Z Obr. 4 je zřejmé, že vygenerovaná $p$-hodnota $\mathrm{v}$ komparaci se stanovenou hladinou významnosti je menší, a tedy došlo k zamítnutí nulové hypotézy. Lze tvrdit, že střední hodnoty nejsou shodné a skupiny vytvořené zvoleným faktorem nejsou podobné. Dále je nutné zjistit, co způsobilo zamítnutí nulové hypotézy. Pomocí Tukeyovy metody mnohonásobného porovnání bylo zjištěno, že statisticky významné jsou př́ijmové skupiny domácností 1 a 6.

Obrázek 5: Výsledné řešení Anovy pro ochotu platit z disponibilního důchodu

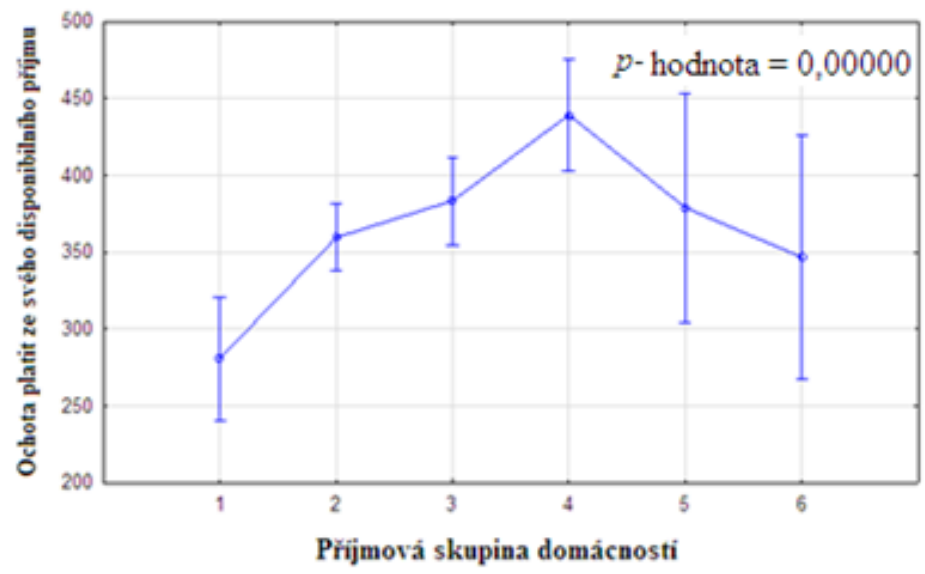

Zdroj: vlastní zpracování dle dotazníkového šetření

Výše uvedený Obr. 5 ukazuje stejné zjištění. Vygenerovaná p-hodnota v komparaci se stanovenou hladinou významnosti je menší. Došlo opět k zamítnutí nulové hypotézy. Tukeyova metoda mnohonásobného porovnání označila za statisticky významné dvojice jednotlivých př́íjmových skupin domácností, a to 1-2, 1-3, 1-4 a 4-2. Lze říci, že je zřejmá diferenciace ochoty platit mezi jednotlivými př́jjmovými skupinami domácností z hlediska daňové asignace a disponibilního důchodu.

\subsection{Analýza ochoty uživatelů knihovny platit alespoň reálné náklady knihovny (VO3)}

Z předchozích závěrů vyplývá, že ochota platit za spotřebovávané služby je poměrně nízká a nedosahuje ani skutečných nákladů přepočtených na čtenáře. Proto Městská knihovna v Praze provedla vnitřní analýzu svých nákladů a došla ke zjištění, že roční provozní náklady knihovny přepočtené na 1 uživatele jsou 1400 Kč (Městská knihovna v Praze). 
Výzkumníci se domnívali, že když respondenti budou uvedeni do ekonomických souvislostí, začnou vnímat i objem jimi spotřebovávaných služeb a dají ji do relace své ochoty zaplatit za dané služby. V dotazníkovém šetření byli uživatelé knihovny speciální otázkou dotazování, zda by byli ochotni knihovně platit 1400 Kč ročně. Výsledky dotazníkového šetření ukazuje Obr. 6.

Obrázek 6: Ochota platit knihovně $1400 \mathrm{Kč/rok} \mathrm{z} \mathrm{disponibilního} \mathrm{důchodu}$

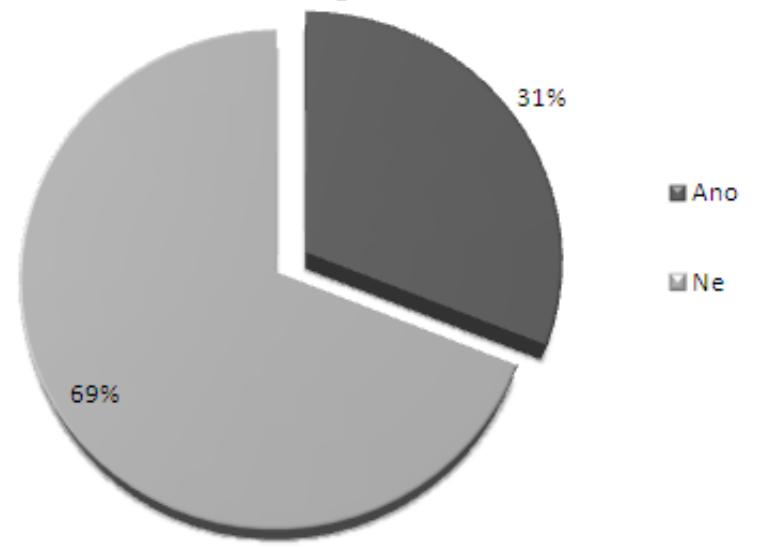

Zdroj: vlastní zpracování dle dotazníkového šetření

Respondenti na tuto částku reagovali tím, že pokud by tato částka měla pocházet z jejich disponibilního důchodu, pak by tuto částku nebyli ochotni knihovně přispívat. Odmítnutí přispět tuto částku se vyjádřilo téměř 69 \% všech platných respondentů (Obr. 6). Obdobné zjištění bylo $\mathrm{v}$ prŕípadě ochoty platit částku $1400 \mathrm{Kč}$ z daňové asignace, kdy se negativně vyjádřilo přibližně $57 \%$.

\section{Závěr}

V současné ekonomické situaci, ve které se většina evropských zemí nachází, jsou velmi aktuální otázky zabývající se množstvím a kvalitou poskytovaných veřejných služeb. Stále častěji dochází k polemikám ohledně dostatečné alokace veřejných finančních prostředků některým poskytovatelům služeb s kolektivní spotřebou. Veřejné služby jsou díky své nehmotnosti, rozmanitosti a rozsahu, ve kterém jsou poskytovány občanům, užitku, hodnotí efektivnosti až způsobem ex post, nebot' pro hodnocení ex ante nemá poskytovatel či donátor dostatek informací a údajů. Proto je nutné získávat další informace a hledat vhodné metodologie, které by napomohly k hodnocení efektivnosti způsobem ex ante. Těmi mohou být moderní analytické prŕstupy typu kontingentních zjišt'ování, které mohou napomoci objasnit význam daných veřejných služeb pro obyvatelstvo. Tyto metody pomohou zajistit optimální alokaci veřejných financí do př́islušného sektoru.

Předložený příspěvek si kladl za cíl prokázat, že spotřebitelé veřejných služeb (na příkladu služeb poskytovaných knihovnami) vnímají jejich užitečnost, dokáží ji kvantifikovat svojí ochotou za tyto služby zaplatit. Z výsledků průzkumu jasně vyplývá, že většina spotřebitelů (80 \%) služby poskytovaných knihovnou vnímá (různou měrou) jako užitečné. Vyplývá tedy i obecnější závěr, že spotřebitelé veřejných služeb jsou schopni ohodnotit užitečnost, která jim plyne ze spotřeby těchto služeb. Je však třeba připustit, že výzkum se zaměřil na zbytné služby. U služeb nezbytných (např́klad zdravotnické služby) bude využití těchto metod také možné, ale výzkumníci musí respektovat korelaci mezi naléhavostí spotřeby služby a ochotou za ni zaplatit v této akutní situaci. 
Další výzkum napomohl odpovědět na několik výzkumných otázek. Z nich vyplývá, že míra užitečnosti se dá analyzovat za pomoci vhodně položených otázek na ochotu spotřebitele platit (je třeba překonat obecnou neochotu spotřebitelů platit za služby, které jsou doposud „Zdarma“ - typicky u knihovnických služeb). Zde se osvědčil přístup WTP s upřesněním, že spotřebitelé rozdělují daň v podobě daňové asignace. Omezení použití tohoto př́stupu je třeba vnímat $\mathrm{v}$ tom, že ukazuje dolní mez pravděpodobného intervalu, ve kterém se pohybuje správný výsledek (kdy potenciální hodnota WTA představuje horní mez). Při použití tohoto př́stupu je třeba vnímat závislost získaných dat na subjektivním názoru respondenta, př́padně na jeho schopnosti takové ohodnocení provést. Stejně tak je třeba upozornit na podstatný vliv př́stupu na vypovídací schopnost a to díky vysoké schopnosti dotazníku, resp. sledu jednotlivých otázek ovlivnit odpovědi respondenta. Pro oceňování veřejných služeb je však tento přístup využíván i přes potenciální rizika, která při použití hrozí. Blíže viz Stejskal et al. (2013). V rámci dílčího výzkumu byly získány odpovědi na hypotézy. Byla potvrzena hypotéza, že ochota platit za službu závisí i na výši důchodu (VO1). Výsledná částka, kterou by respondenti byli ochotni platit knihovně ze svého disponibilního důchodu, odpovídá hodnotě mediánu $200 \mathrm{Kč/rok}$. Respondenti, zastupující věkové kategorie do 26 let a nad 65 let, by byly ochotni ze svého disponibilního důchodu zaplatily nižší částku, a to necelou $100 \mathrm{Kč} /$ rok. Více finančních prostředků by respondenti byli ochotni platit knihovně v př́padě, že by se jednalo o finanční prostředky $\mathrm{z}$ daňové asignace (souhrn výsledkům k VO2) Výsledná částka ročního př́spěvku knihovně vyjádřená hodnotou mediánu je přibližně 450 $\mathrm{K} \check{c}$.

Pokud se respondenti dozvěděli, že skutečné roční náklady přepočtené na jednoho čtenáře u pilotní knihovny jsou 1400 Kč (VO3), bylo zjišt'ováno, zda se jejich ochota platit za skutečně spotřebovávané služby zvýší. Bylo zjištěno, že ochota platit oněch $1400 \mathrm{Kč} \mathrm{je}$ velmi malá (31\%). Výsledek se zásadně nezměnil ani při placení prostřednictvím daňové asignace $(43 \%)$. Tento výsledek nutně vede $\mathrm{k}$ dalším otázkám o vhodnosti použitých metod (metoda WTP a WTA) a jejich vypovídací schopnosti (viz předchozí odstavec), které mohou být předmětem dalších výzkumů (ve vybraných veřejných knihovnách), které by ověřily výsledky provedeného šetření u Městské knihovny v Praze.

\section{Poděkování}

Tento příspěvek vznikl jako součást řešení výzkumné grantové úlohy č. 3052/2012 SOLK s názvem „Metodika měření hodnoty služeb knihoven“, která je financována Ministerstvem kultury ČR.

\section{Literatura}

[1] AABO, S., 2005. Are public libraries worth their price?: A contingent valuation study of Norwegian public libraries. New Library World, 106(11/12), s. 487-495. ISSN 03074803.

[2] AABO, S., 2009. Libraries and return on investment (ROI): A meta-analysis. New Library World, 110(7/8), 311-324. ISSN 0307-4803.

[3] BARRON, D. D., et. al., 2005. The Economic Impact of Public Libraries on South Carolina: A Study Prepared by the School of Library and Information Science, University of South Carolina. Columbia, SC: School of Library and Information Science, University of South Carolina, s. 4 [online]. [vid. 25. července 2012]. Dostupné z: http://www.libsci.sc.edu/SCEIS/exsummary.pdf

[4] BAZALOVÁ, E. Veřejné knihovny a jejich služby [online]. [vid. 25. července 2012]. Dostupné z: http://www.knihzdar.cz/kzv/04-2003/bazalova_Sluzby.htm 
[5] British Library. Measuring our value 2004 [online]. [vid. 25. července 2012]. British Library Annual Report 2003/2004. s. 6. Dostupné z: http://www.bl.uk/pdf/measuring.pdf

[6] Glasgowská deklarace o knihovnách, informačních službách a intelektuální svobodě [online]. [vid. 25. července 2012]. Dostupné z: http://knihovnam.nkp.cz/sekce.php3?page=03_Leg/IFLAglas.htm

[7] GRIFFITHS, J. M. K., D. W. KING and T. LYNCH, 2004a. A Study of Taxpayer Return on Investment (ROI) in Florida Public Libraries: Detailed Result \& Study Methods Part II. Tallahassee, FL: State Library and Archives of Florida.

[8] GRIFFITHS, J. M. K., D. W. KING and T. LYNCH, 2004b. Taxpayer Return on Investment in Florida Public Libraries: Summary Report. Tallahassee, FL: State Library and Archives of Florida.

[9] HÁJEK, P., P. KOŤÁTKOVÁ STRÁNSKÁ and K. MAŤÁTKOVÁ, et al., 2012. Public Services Value Determining - Case of Public Libraries. In: WSEAS Transactions on Environment and Development. Porto: WSEAS Press, s. 140-145. ISBN 978-1-61804102-9.

[10] HARLESS, D. W. and F. R. ALLEN, 1999. Using the Contingent Valuation Method to Measure Patron Benefits of Reference Desk Service in and Academic Library. College \& Research Libraries, 60(1), 56-69. ISSN 0010-0870.

[11] HINDLS, R., S. HRONOVÁ a J. SEGER, et al., 2007. Statistika pro ekonomy. 8. vyd. Praha: Professional Publishing. ISBN 978-80-86946-43-6.

[12] CHUNG, H. K., 2008. The contingent valuation method in public libraries. Journal of Librarianship and Information Science, 40(2), 71-80. ISSN 0961-0006.

[13] KIM, G. A., 2011. Critical review of valuation studies to identify frameworks in library services. Library \& Information Science Research, 33(2), 112-119. ISSN 0740-8188.

[14] Městská knihovna v Praze [online]. [vid. 1. srpna 2012]. Dostupné z: http://www.mlp.cz/cz/

[15] Maine State Library [online]. [vid. 26. července 2012]. Dostupné z: http://www.maine.gov/msl/libs/standards/services.htm

[16] Manifest IFLA/UNESCO o veřejných knihovnách 1994 [online]. [vid. 25. července 2012]. Dostupné z: http://knihovnam.nkp.cz/sekce.php3?page=03_Leg/Manifest_ UNESCO.htm, http://www.skipcr.cz/dokumenty/ifla.pdf

[17] OHIO, S., 2006. Value for Money: Southwestern Ohio's Return from Investment in Public Library. Columbus: Driscoll \& Fleeter.

[18] Služby veřejných knihoven. Směrnice IFLA/UNESCO pro rozvoj. Svaz knihovniků a informačních pracovniků 2002 [online]. [vid. 23. července 2012]. Dostupné z: http://www.ifla.org/VII/s8/news/pg01-cz.pdf

[19] STEJSKAL, J. et al., 2013. Měreni hodnoty veřejných služeb (na př́kladu veřejných knihoven). 1. vyd. Praha: Wolters Kluwer. ISBN 978-80-7478-412-5.

[20] STEJSKAL, J., K. MAŤÁTKOVÁ a P. KOŤÁTKOVÁ STRÁNSKÁ, et al., 2012. Př́stupy ke zjištování hodnoty veřejných služeb vnímané spotřebiteli - aplikace na služby veřejných knihoven. In: Sborník př́spěvkiu z konference Knihovny současnosti 2012. Ostrava: Sdružení knihoven ČR, s. 225-237. ISBN: 978-80-86249-65-0. 
[21] TROSBY, D., 2003. Determining the value of cultural goods: how much (or how little) does contingent valuation tell us? Journal of Cultural Economics, 27(3/4), 275-85. ISSN 0885-2545.

[22] Výroční zprávy Městské knihovny v Praze. Městská knihovna v Praze [online]. [vid. 1. srpna 2012]. Dostupné z: http://www.mlp.cz/cz/o-knihovne/vyrocni-zpravy/

[23] Zákon 257/2001 Sb., o knihovnách a podmínkách provozování veřejných knihovnických a informačních služeb (dále jen „knihovní zákon“). Ministerstvo kultury [online]. [vid. 23. července 2012]. Dostupné z: http://knihovnam.nkp.cz/ sekce.php3?page=03_Leg/01_LegPod/Zakon257.htm 